\title{
RELEVANSI CUM-DIVIDEND DATE DENGAN PERUBAHAN HARGA SAHAM PADA SEKTOR MANUFAKTUR DI BURSA EFEK INDONESIA
}

\author{
Ayu Retsi Lestari', Alfi Arif ${ }^{2}$, Bayu Wijayantini ${ }^{3}$ \\ Universitas Muhammadiyah Jember, Mahasiswa Program Doktor - UNDIP, Semarang
}

\begin{abstract}
This study focuses on analyzing the stock price changes in the days around the cum-dividend date. Cum-dividend date is the date when the shareholdersare entitled to receive the dividend already declared, which will be paid on the pre-determined date. The sample of this study consists of 37 manufacturing companies that are continuously distributing dividends from 2014 to 2016. The results show stock prices tend to be higher on the cum-dividend date. The analysis onyear 2015 data shows that significant stock price differences were found only between the cum-dividend date and the first day after cum-dividend date. Different results are found for data of 2016, where significant stock price differences occur between cum-dividend date and day one, day two, and day three after cum-dividend date. The implication of the research result is that cum-dividend date has the potential to become one of investment strategy in capital market.
\end{abstract}

Keywords $\quad$ : stock price, cum-dividend date, investment strategy

Correspondence to : retsi_ayu@yahoo.co.id, alfi.rif@unej.ac.id, bayu@unmuhjember.ac.id

\begin{abstract}
ABSTRAK
Penelitian ini berfokus pada kajian perubahan harga saham pada hari-hari di sekitar cum-dividend date. Cum-dividend date (hari dengan dividen) adalah tanggal ketika pemilik saham berhak untuk menerima dividen yang telah dinyatakan, yang akan dibayarkan pada suatu waktu. Sampel penelitian ini berjumlah 37 perusahaan manufaktur yang secara terus menerus membagikan dividen tahun 2014 sampai 2016. Hasil penelitian menunjukkan harga saham cenderung lebih tinggi pada cum-dividend date. Pada analisis terhadap data tahun 2015, perbedaan harga saham yang signifikan ditemukan hanya antara cum-dividend date dan hari pertama sesudah. Hasil berbeda ditemukan untuk data tahun 2016, dimana perbedaan harga saham yang signifikan terjadi antara cum-dividend date dan hari pertama, kedua, dan ketiga sesudah cum-dividend date. Implikasi hasil penelitian adalah cum-dividend date berpotensi untuk dijadikan sebagai salah satu strategi berinvestasi di pasar modal.
\end{abstract}

Kata kunci Korespondensi
: harga saham, cum-dividend date, strategi investasi

:retsi_ayu@yahoo.co.id, alfi.rif@unej.ac.id, bayu@unmuhjember.ac.id
PENDAHULUAN / INTRODUCTION

Peran dividen dalam menyiratkan informasi tentang kinerja masa depan dari perusahaan masih merupakan isu yang belum dapat dinyatakan secara pasti dalam bidang keuangan. Perdebatan yang ada mengerucut pada dua hipotesis utama, yaitu hipotesis perataan (smoothing hypothesis) dan

hipotesis sinyal (signaling hypothesis)

(Gumanti, 2013). Hipotesis perataan menduga bahwa keputusan dividen dipengaruhi oleh pencapaian kinerja masa lalu dan saat ini, sementara hipotesis sinyal menduga bahwa dividen memiliki 
kemampuan prediksi atas laba dan harga masa mendatang. Namun demikian, sejauh ini bukti empiris yang ada masih belum menghasilkan kata sepakat, yaitu hipotesis mana yang lebih akurat dalam menjelaskan variabilitas kebijakan dividen yang ada.

Harga saham perusahaan yang melakukan inisiasi pembayaran dividen relatif direspon baik oleh pasar, yaitu ada kenaikan harga saham di pasar modal. Demikian juga halnya dengan perusahaan yang menaikkan besarnya dividen akan diapresiasi oleh pasar. Peneliti yang menguji ada tidaknya dampak inisiasi dividen terhadap harga saham adalah Asquith dan Mullins (1983).

Sebaliknya, perusahaan yang mengurangi atau bahkan menghapus (tidak membayar dividen) akan mendapat pinalti yang cukup signifikan oleh pasar. Pasar akan merasa kecewa jika perusahaan memutuskan untuk menghapus atau menghentikan dividen. Sinyalemen bahwa respon negatif tersebut muncul lebih banyak disebabkan oleh kekuatiran bahwa di masa mendatang kinerja perusahaan akan lebih buruk lagi, sehingga tidak mampu untuk menjamin bahwa pemegang saham akan menerima dividen. Ghosh dan Woolridge (1988) dan Healy dan Palepu (1988) adalah peneliti pertama yang mengungkap keterkaitan antara penghapusan dividen dan harga saham.

Perubahan besar kecilnya dividen bagaimanapun juga merupakan cermin dari kemampuan perusahaan dalam memperoleh laba di masa-masa mendatang. Pasar akan dengan cerdik menyikapi setiap perubahan nilai dividen yang terjadi. Kenaikan dividen seringkali diartikan bahwa manajemen memiliki harapan akan adanya kenaikan laba di tahun-tahun mendatang, sedangkan penurunan dividen menyiratkan penurunan prospek perusahaan.

Penelitian atas respon pasar terhadap kebijakan dividen sejauh ini lebih diarahkan pada ada tidaknya abnormal return di hari atau tanggal pengumuman dividen. Penelitian yang secara khusus mengkaji perubahan harga saham dan volume saham yang diperdagangkan pada hari terakhir dimana pemegang saham masih akan berhak atas dividen (cum-dividend date) belum pernah dilakukan. Perdefinisi hari dengan dividen diartikan sebagai hari terakhir dimana seorang pemegang saham yang tercatat sebagai pemilik masih berhak untuk menerima pembagian dividen di hari yang sudah ditetapkan.

Berdasarkan pada uraian di atas, tujuan penelitian ini adalah untuk menganalisis ada tidaknya perbedaan perubahan harga saham perusahaan di pasar modal jika dikaitkan dengan hari terakhir dimana pemegang saham berhak untuk mendapatkan dividen (hari dengan dividen). Sebanyak 37 perusahaan sector manufaktur yang secara terus menerus membagi dividen tahun 2014-2016 menjadi objek penelitian. Hasil penelitian secara umum menemukan bahwa perbedaan harga saham ditemukan antara hari dengan dividen dan hari pertama sesudah hari dengan dividen untuk data tahun 2015 dan antara hari dengan dividen dan hari pertama, kedua, dan ketiga sesudah hari dengan dividen untuk data tahun 2016.

Artikel ini diatur sebagai berikut. Bagian kedua berisi telaah literatur dan pengembangan hipotesis. Bagian ini diikuti oleh uraian tentang metode penelitian. Bagian empat berisi hasil dan pembahasan. Bagian akhir merupakan penutup yang di dalamnya berisi kesimpulan dan keterbatasan dan saran.

\section{TINJAUAN PUSTAKA DAN PENGEMBANGAN HIPOTESIS}

Sejumlah teori telah dikemukan untuk menjelaskan mengapa terdapat perbedaan besaran dividen antar perusahaan. 
Perbedaan besaran dividen juga ditemukan antar industri (sektor). Dari sejumlah teori yang ada, teori sinyal diviend merupakan salah satu teori yang paling banyak diuji. Dalam hal ini, dividen diyakini sebagi sinyal tentang masa depan perusahaan. Bhattacharya (1979) telah membangun sebuah literatur besar dimana dividen merupakan sinyal dari orang dalam perusahaan kepada pemegang saham mengenai keuntungan masa depan yang diharapkan dari perusahaan dan dukungan bukti empiris sudah banyak ditemukan (Gumanti, 2013).

Dittmar (2000) dan Jagannathan et al. (2000) menguji bentuk dari pembayaran tunai (cash payouts) kepada pemegang saham. Kedua artikel tersebut menyimpulkan bahwa tidak ada satu alasan utama yang menetapkan bentuk dari persentase pembayaran (payout), walaupun apakah itu manajer atau investor memandang dividen sebagai bentuk komitmen tetap dan pembelian kembali saham sebagai mekanisme pembayaran kas sementara.

Hipotesis sinyal dividen menyatakan bahwa besar kecilnya dividen dapat menjadi isyarat atas akan perilaku kinerja perusahaan di masa mendatang. Perusahaan yang menaikkan (menurunkan) dividen menghasilkan abnormal return positif (negatif), jika laba perusahaan naik (turun). Perusahaan dengan informasi campuran (laba naik tapi dividen turun, atau sebaliknya) tidak menghasilkan abnormal return signifikan (Abeyratna et al., 1996). DeAngelo et al. (1996) menemukan kurangnya dukungan bahwa dividen sebagai sinyal. Hal ini bisa jadi disebabkan karena: 1) manajer terlalu optimis memberi sinyal laba yang terlalu optimis, dan 2) dividen adalah hal yang biasa atau tidak istimewa.

Rees (1997) menatakan bahwa laba

yang dibagikan dalam bentuk dividen memiliki dampak yang baik terhadap nilai perusahaan daripada yang menahannya dalam bentuk saldo laba (laba ditahan). Namun demikian, sinyal kenaikan dividen tidak terdukung, hasil yang sebaliknya ditemukan pada perusahaan yang menurunkan dividen (Benartzi et al., 1997).

Berita dividen dan laba tidak mengindikasikan sebagai sinyal atas kinerja jangka panjang perusahaan dan kinerja saham jangka panjang lebih banyak disebabkan oleh kinerja laba daripada dividen (Gunasekarage dan Power, 2006). Mereka mencoba menguji kinerja jangka panjang atas kinerja return dan keuangan perusahaan di Inggris yang dikelompokkan berdasarkan apakah perusahaan tersebut sudah mengubah dividen dan labanya atau tidak. Mereka melakukan penelitian karena terinspirasi oleh penelitian di Amerika yang lebih banyak menekankan kepada perubahan dividen yang ekstrim apakah itu inisiasi atau penghapusan dividen. Selain itu, penelitian-penelitian di Amerika banyak yang tidak menghasilkan konsistensi temuan.

McManus et al. (2006) menguji return saham dari Januari 1959 sampai Desember 1997 dari data London Share Price Database (LSPD). Mereka membentuk portfolio yang mirip dengan model portfolionya Keim (1985). Hasil penelitian menunjukkan bahwa sejarah pembayaran dividen bukan merupakan variabel penentu yang signifikan atas return saham, justru return sebelumnya yang lebih berperan. Namun demikian, kekuatan penjelas yang diteliti semakin menurun dari waktu ke waktu.

Fargher dan Weigand (2009) menyatakan bahwa kandungan informasidividen memiliki dampak yang signifikan terhadap harga saham. Mereka menggunakan cumulative abnormal return (CAR) untuk melakukan analisis. Mereka menemukan hubungan yang positif dan signifikan antara CAR dan profitabilitas 
perusahaan dan harga sahamnya. Namun demikian, sejumlah penelitian justru menemukan adanya hubungan negatif antara CAR dan risiko (Frankfurter dan Wood, 2002; Bozos et al., 2011). Terkait dengan pengujian keterkaitan pengumuman dividen dengan return saham di sekitar hari-hari pengumuman, hasil penelitian menyimpulkan bahwa perusahaan menghasilkan CAR positif dan signifikan pada tanggal pengumuman. Mereka menemukan semua variabel tertentu perusahaan yang signifikan dan positif dalam hubungan dengan CAR. How et al. (2011) menguji reaksi investor pasar untuk pengumuman dividen dan menemukan bahwa harga saham meningkat. Berdasarkan bukti tersebut How et al. menyatakan bahwa temuan mereka memvalidasi teori sinyal. Fama (1970) mempelajari fenomena dan menyimpulkan bahwa kandungan informasi dividen signifikan. Dividen tersebut memberikan sinyal kepada investor tentang tren masa depan harga saham bergerak.

Al-Yahyaee et al. (2011) meneliti reaksi harga saham terhadap pengumuman dividen kas oleh perusahaan yang terdaftar di Muscat Securities Market (MSM) untuk mengidentifikasi apakah atau tidak dividen tersebut berisi informasi yang relevan dengan pembentukan harga. Hasil penelitian menunjukkan bahwa pengumuman meningkatnya dividen terkait dengan peningkatan harga saham, sementara pengumuman dividen menurun menyebabkan penurunan harga saham. Perusahaan yang tidak mengubah dividen mereka mengalami hasil negatif tidak signifikan

Lee et al. (2012) meneliti keterkaitan perubahan dividen dengan perubahan laba dan perubahan harga saham pada perusahaan yang tercatat di Bursa Saham Malaysia. Mereka menemukan bahwa perubahan dividen sangat terkait dengan perubahan laba kontemporer, walaupun keterkaitan tersebut melemah pada periode satu tahun ke depan dan sebagian besar tidak berhubungan dengan perubahan laba lebih dari satu tahun. Selanjutnya, mereka menemukan bukti lemah bahwa ukuran perubahan dividen terkait dengan profitabilitas masa depan. Mereka juga menemukan bahwa kenaikan dividen pada tahun-tahun awal pemulihan krisis keuangan Asia 1997 terkait dengan peningkatanendapatan satu tahun ke depan. Mereka menyatakan bahwa stabilitas dividen mungkin terkait langsung dengan kandungan informasi pada pendapatan masa depan.

Yip et al. (2010) meneliti reaksi pasar terhadap pengumuman dividen di pasar modal Malaysia dan secara umum menemukan bukti yang mendukung hipotesis sinyal (signaling hypothesis). Artinya, perubahan dividen yang terjadi di pasar modal Malaysia merupakan salah satu sumber informasi penting dalam kaitannya dengan keputusan investasi investor di pasar modal.

Literatur keuangan perusahaan yang menyoroti reaksi pasar terhadap pengumuman dividen melaporkan hasil yang beragam. Beberapa studi mendukung respon positif dari pasar sebagai akibat dari pengumuman dividen sedangkan beberapa laporan menunjukkan respon pasar adalah negatif. Bahsir et al. (2013) berupaya untuk meneliti reaksi pasar yang heterogen atas pengumuman dividen pada 73 perusahaan yang terdaftar di Bursa Efek Karachi. Mereka menyelidiki fenomena ini dengan metodologi baru dengan menggunakan dua metode, yaitu event study dan regresi multivariat untuk kemungkinan efek faktor spesifik perusahaan yang terkait dengan pengumuman dividen. Mereka melaporkan bahwa reaksi pasar adalah salah satu sisi sebagai mayoritas perusahaan dalam sampel yang dengan cumulative abnormal return positif untuk periode tertentu. Dalam hal ini, mereka tidak bisa mengabaikan pentingnya faktor spesifik perusahaan yang memiliki efek pada dividen 
tapi mereka tetap berani untuk menyimpulkan bahwa mayoritas perusahaan di periode sampel menggambarkan kumulatif return abnormal positif dan reaksi pasar positif. Bahsir et al. menyimpulkan bahwa secara keseluruhan temuan mereka mampu menjawab pertanyaan mengenai kandungan informasi dividen informasi dimana investor di pasar bisa mendapatkan return positif sebagai respon daripengumuman dividen.

Berpijak dari uaraian di atas, hipotesis penelitian adalah sebagai berikut:

$\mathrm{H}_{1}$ Perubahan harga saham di hari cumdividend date lebih tinggi daripada pada hari-hari sebelumdan sesudah cumdividend date.

\section{METODE PENELITIAN / METHODS}

Populasi penelitian ini adalah semua saham yang membagikan dividen tunai tahun 2014 sampai 2016, yang berarti mencakup empat tahun analisis. Sampel penelitian ditetapkan dengan metode purposive sampling. Kriteria untuk menetapkan sampel penelitian adalah sebagai berikut:

1. Perusahaan harus sudah menjadi perusahaan publik tahun 2012 (melakukan penawaran saham perdana tahun 2012). Hal ini disyaratkan untuk menghindari bias pada besaran dividen pada saat perusahaan masih menjadi perusahaan privat dimana jumlah sahamnya cenderung sedikit dibandingkan dengan setelah menjadi perusahaan publik.

2. Perusahaan harus membagikan dividen secara terus menerus selama tiga tahun analisis (2014-2016). Hal ini disyaratkan untuk mendapatkan konsistensi dalam penilaian pasar guna menghindari bias atas adanya kemungkinan perusahaan membayar dividen di tahun 2015, padahal pembagian dividen tersebut baru dilakukan tahun tersebut (inisiasi dividen).

3. Saham perusahaan yang membagi dividen harus likuid dengan kriteria setidaknya ditransaksikan minimal sebanyak 150 hari dalam setahun.

Variabel penelitian ini ada dua, yaitu besaran dividen dan harga saham. Semua variabel diukur dengan menggunakan skala rasio.Metode analisis yang digunakan untuk menjawab tujuan penelitian adalah uji beda rata-rata ( $t$-test for mean difference). Uji ini dilakukan untuk menjawab hipotesis apakah ada perbedaan harga saham pada hari-hari di sekitar hari dengan dividen. Artinya, apakah ada perubahan harga saham di hari-hari sekitar hari dengan dividen.

\section{HASIL PENELITIAN / RESULTS Proses Pemilihan Sampel}

Sampel penelitian dipilih sesuai dengan kriteria, yaitu perusahaan harus membayarkan dividen selama tiga tahun berturut-turut (2014-2016) dan saham perusahaan aktif diperdagangkan, yaitu setidaknya dalam setahun minimal ditransaksikan selama 150 hari. Tabel 1 menyajikan data tentang perusahaan manufaktur sampai dengan tahun 2016 dan sampel yang terpilih pada masing-masing sektor yang tergolong ke dalam sektor manufaktur. Sampai dengan tahun 2016, terdapat 148 perusahaan di sektor manufaktur. Dari 148 perusahaan tersebut terdapat 37 perusahaan yang memenuhi kriteria yang akhirnya terpilih sebagai sampel penelitian. Persentase terbanyak sampel penelitian ditemukan pada sektor Barang Konsumsi, yaitu 15 perusahaan. 
Balance Vol. XV No. 2 | Juli 2018

Tabel 1. Distribusi Sampel Penelitian Berbasis Sektor

\begin{tabular}{|c|l|c|c|c|r|}
\hline No & \multicolumn{1}{|c|}{ Sektor } & $\begin{array}{c}\text { Jumlah } \\
\text { Perusahaan }\end{array}$ & Persentase & $\begin{array}{c}\text { Jumlah } \\
\text { Sampel }\end{array}$ & Persentase \\
\hline 1 & Industri Dasar dan Kimia & 66 & $44,59 \%$ & 10 & $15,15 \%$ \\
\hline 2 & Aneka Industri & 43 & $29,05 \%$ & 12 & $27,91 \%$ \\
\hline 3 & Barang Konsumsi & 39 & $26,35 \%$ & 15 & $38,46 \%$ \\
\hline & Total & 148 & $100,00 \%$ & 37 & $25,00 \%$ \\
\hline
\end{tabular}

Sumber: JSX Factbook 2016.

\section{Deskriptif Statistik Variabel Penelitian}

Tabel 2 menyajikan deskripsi statistik variabel-variabel penelitian berbasis total sampel dan sektor. Pada tabel tersebut, Panel A, dapat diketahui bahwa untuk data tahun 2015, harga saham pada saat hari dengan dividen lebih tinggi dariapda rata-rata harga saham pada hari-hari di sekitar hari dengan dividen, kecuali pada hari minus 1 , dimana rata-rata harga saham lebih tinggi daripada rata-rata harga saham saat hari dengan dividen. Pengamatan lebih detail menunjukkan bahwa nilai rata-rata harga saham pada hari minus 1 ditemukan pada sektor Industri Dasar dan Kimia dan sektor Barang Konsumsi. Temuan pada Panel A mengindikasikan bahwa ada penignkatan harga pada saat hari dengan dividen dibandingkan dengan hari-hari lain di sekitar hari dengan dividen. Tersirat pada temuan ini adalah investor memanfaatkan peluang untuk mendapatkan dividen

Tabel 2. Deskripsi Statistik Variabel-variabel Penelitian

\begin{tabular}{|l|r|r|r|r|r|r|r|r|}
\hline \multirow{2}{*}{ Keterangan } & \multicolumn{7}{|c|}{ Harga Saham Rata-rata Hari } \\
\cline { 2 - 9 } & Minus 3 & Minus 2 & Minus 1 & Cum-Div & Plus 1 & Plus 2 & Plus 3 \\
\hline Panel A: Tahun 2015 & 8.067 & 8.054 & 8.102 & 8.076 & 7.970 & 8.030 & 8.005 \\
\hline Total Sampel & 13.150 & 13.172 & 13.332 & 13.305 & 13.117 & 13.087 & 13.079 \\
\hline Industri Dasar dan Kimia & 7.568 & 7.551 & 7.528 & 7.557 & 7.435 & 7.589 & 7.474 \\
\hline Aneka Industri & 5.077 & 5.044 & 5.076 & 5.005 & 4.968 & 5.012 & 5.047 \\
\hline Barang Konsumsi & 9.757 & 9.755 & 9.740 & 9.848 & 9.675 & 9.680 & 9.744 \\
\hline Panel B: Tahun 2016 & 18.371 & 18.359 & 18.295 & 18.715 & 18.319 & 18.421 & 18.496 \\
\hline Total Sampel & 8.649 & 8.516 & 8.468 & 8.468 & 8.358 & 8.348 & 8.471 \\
\hline Industri Dasar dan Kimia & 4.901 & 5.010 & 5.054 & 5.041 & 4.966 & 4.919 & 4.929 \\
\hline Aneka Industri & \multicolumn{7}{|c|}{ dividen. Data ini sama dengan data pada } \\
\hline Barang Konsumsi &
\end{tabular}

Pergerakan harga saham pada tahun 2016, Panel B, menunjukkan data harga saham lebih tinggi pada hari dengan dividen dibandingkan dengan hari-hari di sekitarnya. Data untuk masing-masing sektor menunjukkan sektor Barang Konsumsi dimana harga saham pada hari minus 1 lebih tinggi daripada pada saat hari dengan tahun 2015 .

Secara umum, baik untuk data tahun 2015 maupun data tahun 2016, rata-rata harga saham saat hari dengan dividen lebih tinggi daripada rata-rata harga saham harihari lain di sekitar cum-dividend data. Dengan kata lain, tersirat bahwa investor meningkatkan minat membeli saham pada 
saat hari dengan dividen sebagai salah satu upaya untuk mendapatkan dividend dan melepas saham pada hari setelah hari dengan dividen.

\section{Pengujian Hipotesis}

Hasil uji statistik atas ada tidaknya perbedaaan harga pada hari-hari di sekitar hari dengan dividen ditunjukkan pada Tabel 3 untuk tahun 2015 dan 2016. Pengujian yang dilakukan dan ditampilkan pada Tabel 3 diddasarkan pada nilai rata-rata harian, baik untuk hari-hari sebelum hari dengan dividen maupun setelah hari dengan dividen. Selain itu, pengujian juga dilakukan dengan membandingkan keseluruhan hari dari sebelum dan sesudah hari dengan dividen, yaitu tiga hari sebelum dan tiga hari sesudah, dengan harga rata-rata pada hari dengan dividen.

Tampak pada Tabel 3, secara rata-rata harga saham pada saat hari dengan dividen lebih tinggi daripada rata-rata harga saham pada hari-hari sebelum maupun sesudah hari dengan dividen baik untuk tahun 2015 maupun tahun 2016. Hanya satu kejadian di mana rata-rata harga saham adalah lebih tinggi daripada rata-rata harga saham pada saat hari dengan dividen, yaitu pada hari minus 1 tahun 2015.

Untuk data tahun 2015, Panel A, dari delapan pengujian yang dilakukan, perbedaan nilai rata-rata antara hari yang diujikan dan hari cum-dividend ditemukan hanya pada hari plus 1, yaitu satu hari setelah hari dengan dividen. Artinya, pada hari plus 1 setelah hari dengan dividen, rata-rata harga saham secara statistik lebih rendah daripada harga pada saat hari dengan dividen.

Tabel 3 Hasil Pengujian Perbedaan Harga di Sekitar Cum-Dividend Date

\begin{tabular}{|c|c|c|c|c|c|}
\hline Keterangan & $\begin{array}{c}\text { Rata-rata } \\
\text { Harga Saat } \\
\text { Hari Uji }\end{array}$ & $\begin{array}{c}\text { Rata-rata } \\
\text { Harga Saat } \\
\text { CumDiv }\end{array}$ & $\begin{array}{c}\text { Beda } \\
\text { Rata-rata }\end{array}$ & t-stat & Sig. \\
\hline \multicolumn{6}{|c|}{ Panel A: Tahun 2015} \\
\hline Minus $3-$ Cum Div & $8.066,7$ & $8.075,8$ & $-9,1$ & $-0,1218$ & 0,4518 \\
\hline Minus $2-$ Cum Div & $8.053,8$ & $8.075,8$ & -22 & $-0,3103$ & 0,3790 \\
\hline Minus $1-$ Cum Div & $8.102,4$ & $8.075,8$ & 26,6 & 0,6865 & 0,2483 \\
\hline Plus 1 - Cum Div & $7.970,4$ & $8.075,8$ & $-105,4$ & $-3,0859$ & $\mathbf{0 , 0 0 1 9}$ \\
\hline Plus 2-Cum Div & $8.030,3$ & $8.075,8$ & $-45,5$ & $-0,7776$ & 0,2209 \\
\hline Plus 3-Cum Div & $8.005,0$ & $8.075,8$ & $-70,8$ & $-1,0991$ & 0,1394 \\
\hline Minus 3-1 - Cum Div & $8.074,3$ & $8.075,8$ & $-1,5$ & $-0,0258$ & 0,4897 \\
\hline Plus 1-3 - Cum Div & $8.001,9$ & $8.075,8$ & $-73,9$ & $-1,6476$ & 0,0541 \\
\hline \multicolumn{6}{|c|}{ Panel B: Tahun 2016} \\
\hline Minus 3 - Cum Div & $9.756,9$ & $9.848,1$ & $-91,2$ & $-0,8596$ & 0,1978 \\
\hline Minus $2-$ Cum Div & $9.754,8$ & $9.848,1$ & $-93,3$ & $-1,2108$ & 0,1169 \\
\hline Minus 1 - Cum Div & $9.739,7$ & $9.848,1$ & $-108,4$ & $-1,2805$ & 0,1042 \\
\hline Plus 1 - Cum Div & $9.675,1$ & $9.848,1$ & -173 & $-2,1034$ & $\mathbf{0 , 0 2 1 2}$ \\
\hline Plus $2-$ Cum Div & $9.680,4$ & $9.848,1$ & $-167,7$ & $-1,8876$ & $\mathbf{0 , 0 3 3 5}$ \\
\hline Plus 3-Cum Div & $9.744,3$ & $9.848,1$ & $-103,8$ & $-1,9664$ & $\mathbf{0 , 0 2 8 5}$ \\
\hline Minus 3-1 - Cum Div & $9.750,5$ & $9.848,1$ & $-97,6$ & $-1,1498$ & 0,1288 \\
\hline Plus 1-3-Cum Div & $9.699,9$ & $9.848,1$ & $-148,2$ & $-2,0898$ & 0,0219 \\
\hline
\end{tabular}


Hasil berbeda ditemukan pada pengujian untuk data tahun 2016, Panel B. Dari delapan pengujian, perbedaan nilai ratarata ditemukan signifikan pada empat hari, yaitu hari plus 1 , plus 2 , plus 3 , dan keseluruhan hari setelah hari dengan dividen. Pada keempat pengujian tersebut, harga saham secara rata-rata ditemukan lebih rendah daripada rata-rata harga saham pada saat hari dengan dividen.

Berdasarkan pada hasil pengujian yang ditunjukkan dalam Tabel 3, dapat dinatakan bahwa untuk data tahun 2015, penelitian ini tidak menemukan adanya perbedaan nilai rata-rata harga saham antara hari-hari di sekitar hari dengan dividen dan hari dengan dividen. Perbedaan rata-rata harga saham hanya ditemukan pada satu hari setelah hari dengan dividen. Dengan demikian, untuk data tahun 2015 hipotesis penelitian yang menyatakan bahwa "Perubahan harga saham di hari hari dengan dividen lebih tinggi daripada pada hari-hari sebelumdan sesudah hari dengan dividen" tidak dapat diterima. Artinya, kenaikan harga saham pada saat hari dengan dividen secara statistik tidak berbeda dengan rata-rata harga saham di sekitar hari dengan dividen.

Hasil pengujian untuk data tahun 2016 menunjukkan temuan cukup berbeda dengan data tahun 2015. Pada tahun 2016, ditemukan harga saham setelah hari dengan dividen secara statistik lebih rendah daripada saat hari dengan dividen. Dengan demikian, hipotesis penelitian yang menyatakan "Perubahan harga saham di hari cumdividend date lebih tinggi daripada pada harihari sebelum dan sesudah cum-dividend date" diterima.

\section{PEMBAHASAN / DISCUSSION}

Penelitian ini menemukan bahwa harga saham mengalami peningkatan secara ratarata pada hari dengan dividen. Hasil ini menyiratkan adanya upaya dari investor untuk menambah portofolio mereka pada hari dengan dividen dalam upaya untuk memperoleh dividen. Sebagaimana diketahui, investor (pemegang saham) akanyang memiliki saham pada hari hari dengan dividen dan menahannya pada hari itu berhak untuk menerima pembagian dividen. Walaupun esok harinya mereka melepas atau menjual saham yang dimiliki, mereka masih tetap berhak menerima dividen yang dibagikan oleh perusahaan. Temuan ini menyiratkan dengan jelas bahwa hari dengan dividen dapat dijadikan sebagai salah satu strategi untuk meraup keuntungan berinvestasi saham di pasar modal. Artinya, fenomena hari dengan dividen dapat menjadi sebuah alternatif memakmurkan diri dengan harapan menerima dividen pada saat pembagian di kemudian hari.

Tujuan utama penelitian ini adalah untuk menemukan bukti apakah harga saham akan berubah pada hari-hari di sekitar hari dengan dividen. Dengan harapan akan diterimanya dividen jika pada hari dengan dividen investor masih memegang saham sebuah perusahaan, harga saham seharusnya akan naik menjelang hari dengan dividen dan pada hari dengan dividen lalu akan turun setelah hari dengan dividen. Artinya, perilaku investor untuk mendapatkan dividen dengan membeli saham pada saat hari dengan dividen dan melepasnya setelah hari dengan dividenakan membuat harga saham naik menjelang hari dengan dividen dan turun setelahnya.

Secara sekilas, penelitian ini menemukan bahwa harga saham secara ratarata naik atau lebih tinggi pada hari dengan dividen dibandingkan dengan harga saham sebelum atau sesudah hari dengan dividen. Secara khusus, rata-rata harga saham ditemukan lebih tinggi pada hari minus 1 dibandingkan dengan pada saat hari dengan dividen untuk tahun 2015. Secara khusus juga ditemukan fenomena tersebut berlaku 
untuk sector Barang Konsumsi, tetapi tidak berlaku pada dua sektor yang lain, yaitu Industri Dasar dan Kimia dan Aneka Industri.

Hasil pengujian atas ada tidaknya perbedaan harga antara hari-hari sekitar hari dengan dividen dan saat hari dengan dividen untuk data tahun 2015 pada perusahaan sektor manufaktur di Bursa Efek Indonesia menunjukkan ada bukti yang tidak konsisten. Untuk data tahun 2015, penelitian ini menemukan perbedaan harga yang secara statistik adalah signifikan hanya pada satu hari setelah hari dengan dividen, dimana harga saham secara rata-rata lebih rendah daripada harga saat hari dengan dividen. Pengujian pada hari-hari yang lain tidak menunjukkan adanya perbedaan harga yang secara statistik siginifkan. Artinya, secara umum, pada hari minus 3 , minus 2 , minus 1 , plus 2 , dan plus 3 , harga saham relatif sama dibandingkan dengan harga saham pada saat hari dengan dividen. Penggunaan data berbasis nilai rata-rata antara sebelum dan juga sesudah hari dengan dividen tidak memengaruhi kesimpulan umum bahwa harga saham secara rata-rata relatif tidak berbeda antara sebelum, sesudah dan saat hari dengan dividen.

Hasil yang sedikit banyak berbeda ditemukan untuk data tahun 2016. Pada tahun 2016, ditemukan secara rata-rata harga saham setelah hari dengan dividen lebih rendah daripada saat hari dengan dividen. Temuan ini identik dengan yang dilaporkan oleh Isaksson (2013). Hasil tersebut konsisten untuk data yang didasarkan pada nilai ratarata semua hari setelah hari dengan dividen. Artinya, investor relatif memiliki perilaku yang seragam yaitu mereka melepas saham setalah hari dengan dividen. Hal tersebut membuat harga saham turun dan hasil pengujian secara statistik mendukung temuan tersebut.

Hasil yang ditemukan pada tahun 2016 mendukung teori bahwa investor akan memanfaat hari terakhir dimana mereka akan menerima dividen jika masih tercatat sebagai pemegang saham, yaitu hari dengan dividen. Tersirat dengan jelas pada kondisi di tahun 2016 adalah dividen merupakan sinyal bagi investor untuk membeli saham untuk meningkatkan kemakmurannya melalui harapan untuk menerima dividen. Bukti ini setidaknya dapat dijadikan sebagai bukti awal untuk mendukung teori sinyal dividen (Bhattacharya, 1979). Teori sinyal (signaling theory) menyatakan bahwa dividen akan mengurangi ketimpangan informasi antara manajemen dan pemegang saham dengan menyiratkan informasi privat tentang prospek masa depan perusahaan (Tsuji, 2012; Cherkasova dan Petrukhin, 2016). Para pendukung teori sinyal percaya bahwa kebijakan dividen suatu perusahaan digunakan sebagai suatu cara untuk menyiratkan pesan kualitas dan biaya yang dikeluarkan oleh perusahaan diyakini relatif lebih rendah daripada alternatif-alternatif yang lain.

Hasil penelitian ini setidaknya mampu mengkonfirmasi apa yang iungkapkan di dalam literatur bahwa hari dengan dividen dapat dijadikan sebagai salah dasar bagi investor dalam membangun portofolio. Gumanti (2013) menyajikan diskusi cukup lengkap tentang teori sinyal dividen. Namun demikian, hasil penelitian ini harus dicermati lebih hati-hati karena perbedaan harga saham yang dilaporkan baru ditemukan untuk satu tahun amatan dan itupun ditemukan pada hari-hari setelah hari dengan dividen. Walaupun sekilas temuan pada tahun 2016 tersebut mendukung konsep kecepatan reaksi investor dalam membangun portofolio investasinya, kita dapat menjadikan temuan ini sebagai batu loncatan untuk melakukan evaluasi lebih mendalam atas perilaku investor dalam memanfaatkan segala peluang memperoleh keuntungan di pasar modal. 
Implikasi mendasar dari hasil temuan yang dilaporkan dalam penelitian ini adalah, kita dapat menjadikan peristiwa hari dengan dividen sebagai salah satu strategi dalam memperoleh keuntungan di pasar modal. Strategi yang dapat dipilih investor ada dua. Pertama, investor dapat membeli saham pada hari-hari menjelang hari dengan dividen dan menjualnya pada saat hari dengan dividen. Pada situasi ini, investor berpotensi akan memperoleh capital gain. Kedua, investor dapat membeli saham pada hari-hari menjelang hari dengan dividen dan menjualnya pada hari setelah hari dengan dividen. Pada situasi ini, investor mungkin mengalami kerugian investasi (capital loss), tetapi besarnya dividen yang akan diterima beberapa hari kemudian dapat menutup kerugian karena turunnya harga.

\section{KESIMPULAN / CONCLUSSION}

Penelitian ini bertujuan untuk menganalisis apakah harga saham perusahaan mengalami perubahan signifikan pada harihari hari dengan dividen. Hasil penelitian pada 37 perusahaan sektor manufaktur tahun 2015 dan 2016 menunjukkan bahwa dapat secara rata-rata, harga saham pada hari dengan dividen lebih tinggi daripada pada hari-hari sebelum dan sesudah hari dengan dividen. Hasil pengujian dengan analisis uji beda rata-rata menunjukkan bahwa secara statistik rata-rata harga saham perusahaan hari dengan dividen lebih tinggi daripada sesudah hari dengan dividen untuk data tahun 2016. Untuk data tahun 2015, perbedaan yang signifikan hanya ditemukan pada satu hari setelah hari dengan dividen. Secara umum, penelitian ini menyiratkan dukungan bahwa hari dengan dividen dapat menjadi sinyal baik bagi investor untuk memperoleh dividen dalam rangka untuk meningkakan kemakmurannya dengan berinvestasi pada saham dan hari dengan dividen dapat dijadikan sebagai salah satu strategi berinvestasi saham.

\section{Keterbatasan dan Saran}

Penelitian ini mendeteksi dua kelemahan yang bisa menjadi batu pijakan untuk dilakukan perbaikan guna melakukan penelitian lanjutan. Pertama, penelitian ini hanya mengamati perubahan harga saham sebagai akibat dari hari dengan dividen dalam dua periode, sehingga hasil penelitian belum dapat dikatakan kuat untuk menarik kesimpulan bahwa fenomena tersebut berlaku secara umum. Oleh karena itu, penelitian yang akan datang dapat mengembangkan analisis dengan memperpanjang periode amatan untuk mendapatkan konsistensi hasil yang lebih baik. Kedua, penelitian ini hanya sebatas menganalisis pergerakan harga saham untuk mendeteksi ada tidaknya efek peristiwa hari dengan dividen terhadap perubahan harga saham. Analisis berbasis harga saham saja belum mampu untuk mencakup efek risiko inevstasi saham. Oleh karena itu, penelitain yang akan datang dapat dilakukan dengan menggunakan basis uji efisiensi pasar bentuk semi kuat yang didasarkan pada analisis atas ada tidaknya perubahan abnormal return saham, bukan saja pada harga saham.

\section{DAFTAR PUSTAKA / BIBLIOGRAPHY}

Abeyratna, G., A. Lonie, D. Power, dan C. Sinclair. 1996. The influence of company financial performance on the interpretation of dividend and earnings signals: A study of accounting and market based data, British Accounting Review, 28(3), 229-247.

Aharony, J. dan I. Swary. 1980. Quarterly dividends and earnings announcement and stockholders' return: An empirical analysis, Journal of Finance, 35(1), 112.

Al-Yahyaee, K.H., T.M. Pham, dan T.S. Walter. 2011. The information content of cash dividend announcements in a unique 
environment, Journal of Banking \& Finance, 35(3), 606-612.

Asquith, P., dan D. W. Mullins, Jr. 1983. The impact of initiating dividend payments on shareholders' wealth, Journal of Business, 56(1), 77-96.

Baker, K.H., S. Samir, S. Dutta, dan D. Gandhi. 2007. The perception of dividends by Canadian managers: New survey evidence, International Journal of Managerial Finance, 3(1), 70-91.

Bashir, U., S.Z. A. Shah, dan M. Hussain. 2013. On the differential market reaction to dividend announcement: Evidence from an emerging equity market, Financial Assets and Investing, 3(1), 7-24.

Benartzi, S., R. Michaely, dan R.H. Thaler. 1997. Do changes in dividends signal the future or the past?, Journal of Finance. 52(3), 1007-1034.

Bhattacharya, S. 1979. Imperfect information, dividend policy, and 'the bird in the hand' fallacy, Bell Journal of Economics. 10(1), 259-270.

Bozos, K., K. Nikolopoulos. Dan G. Ramgandhi. 2011. Dividend signaling under economic adversity: Evidence from the London Stock Exchange, International Review of Financial Analysis. 20(5), 364-374.

Cherkasova, V.A. dan Petrukhin, V.V. 2017. The ex-day phenomenon and share price performance on emerging markets, Journal of Coporate Finance Research, 11(1): 16-36.

DeAngelo, H., L. DeAngelo, dan D.J. Skinner. 1996. Reversal of fortune: Dividend signaling and the disappearance of sustained earnings growth, Journal of Financial Economics. 40(3), 341-371.

Fama, E.F.1970. Efficient Capital markets: A review of theory and empirical work. The Journal of Finance. 25(2), 383-417.

Fargher, N.L. dan R.A. Weigand. 2009. Crosssectional differences in the profits, returns and risk of firms initiating dividends, Managerial Finance. 35(6), 509-530.

Frankfurter, G.M. danB.G. Wood Jr. 2002. Dividend policy theories and their empirical tests, International Review of Financial Analysis. 11(2), 111-138.

Ghosh, C. dan R.J. Woolridge. 1988. An analysis of shareholder reaction to dividend cuts and omissions, Journal of Financial Research. 11(4), 281-294.

Gumanti, T.A. 2013. Kebijakan Dividen: Teori, Empiris dan Implementasi. Yogyakarta: UPP-STIM YKPN.

Gunasekarage, A. dan D.M. Poyer. 2006. Anomalous evidence in dividend announcement effect, Managerial Finance. 32(3), 209-226.

Healy, P. M., dan K.G. Palepu, 1988, Earnings information conveyed by dividend initiations and omissions, Journal of Financial Economics. 21(2), 149-175.

How, J.C., K. Ngo. dan P. Verhoeven. 2011. Dividend initiations and long-run IPO performance, Australian Journal of Management. 36(2), 267-286.

Isaksson, A. 2013. The ex-dividend-day price behaviour of blue-chip stocks: International evidence, Asian Journal of Finance \& Accounting. 5(1): 73-88.

Lease, R. C., K. John, A. Kalay, U. Loewenstein, dan O. H. Sarig. 2000. Dividend Policy: Its Impact on Firm Value, Harvard Business School Press, Boston, Massachusetts.

Lee, S.P., M. Isa, dan W.L. Lim. 2012. Dividend changes and future profitability: evidence from Malaysia, Asian Academy of Management Journal of Accounting and Finance. 8(2), 93-110.

McManus, I.D., A. Gwilym, dan S.H. Thomas. 2006. Payment history, past returns and the performance of UK zero dividend stocks, Managerial Finance. 32 (6), 518536.

Rees, W. 1997. The impact of dividends, debt and investment on valuation models, Journal of Business Finance \& Accounting. 27(7\&8), 1111-1140.

Tsuji, C. 2012, A discussion on the signaling hypothesis of dividend policy, The Open Business Journal. 5, 1-7 
Balance Vol. XV No. 2 | Juli 2018

Wijayantini, B., \& Sari, M. I. (2017). Hubungan Kinerja Keuangan dan Rasionalitas Investor Industri Makanan Minuman Syariah yang Listed Di Bursa Efek Indonesia (BEI). Balance, 14(02).

Yip, P. P., M. Isa, G.W. Kester, dan S.P. Lee. 2010, Share price reaction to dividend announcements and the interaction with earnings announcements in the Malaysian stock market, Asian Journal of Business and Accounting. 3(2), 101120. 